\title{
Wu Huiyi
}

Traduire la Chine au XVIII e siècle: Les jésuites traducteurs de textes chinois et le renouvellement des connaissances européennes sur la Chine (1687-ca. 1740). Paris:

Honoré Champion, 2017. Pp. 493. Pb, € 75,85 .

For the past half century, scholars of the Jesuits' China mission in the early modern period have concentrated their analyses on its intellectual aspects. The fascination with intercultural dialogue is understandable, as is the concern with tracing the genealogies of modern areas of academic investigation. Both scholarly impulses seek to shed light on cases from the past which may be fruitfully compared to today's preoccupations. But while the field of studies on the China mission has grown dramatically since the waning decades of the last century - with a concomitant expansion of areas of inquiry about the lives of missionaries, their Chinese adherents and antagonists, and the material culture of the missions - there still remain compelling questions to be resolved in its intellectual history. Wu Huiyi's Traduire la Chine au XVIIIe siècle, is an excellent example of how to approach such questions and a masterful display of investigative ability on the part of a young scholar.

The primary concern of this book is to examine the reading habits and cultural awareness of the Jesuits of the French mission, whose members arrived in Qing Empire after 1687 as a group independent of the Society's Vice-Province of China. Those familiar with the printed texts that appeared from French publishers in the late seventeenth and early eighteenth century are certainly aware of the voluminous quality of those sources, and the sheer amount of sifting through Chinese information - whether from human or textual sources- that underlay them. The precise identification of those sources, however, has long seemed an unsolvable mystery owing to the plethora of vague references to Chinese books and unstable systems of romanization (challenges that confront those working on not only the French Jesuits' output, but also that of the missionaries of the Vice-Province, and their counterparts in Japan, Southeast Asia, and South Asia). Thanks to her deep familiarity with Chinese texts, and a few felicitous discoveries in the archives, however, Wu Huiyi has identified several of the books that informed her chosen French authors, and in some cases the particular editions that were used.

In a highly detailed and logically conceived analysis, Wu Huiyi guides the reader through the processes by which some of the most prolific French Jesuit authors became familiar with Chinese authors, and how they rendered these texts into French for European readers. Here, we see her concern with the Jesuits' choices of what to read, which in turn leads to a sustained 
discussion of their engagement with books and their authors, as well as the literary context of the early Qing era. We also see Wu's concern for how they read and, by extension, how they used what they read for edifying and curious ends, as well as polemical ones. These terms invoke the intellectual struggles of the age of Louis XIV and XV, when Jesuit authors published in France defenses of their missionary strategies as protagonists in the Chinese Rites controversy, as well as accounts of their apostolic enterprises mingled with information about indigenous thought, manufactures, culture, and medicine in the Lettres édifiantes et curieuses (published annually after 1702), as well as in stand-alone volumes of encyclopedic ambitions, in particular the Description géographique, historique, chronologique, politique et physique de l'Empire de la Chine et de la Tartarie chinoise (Paris, 1735).

Wu Huiyi disentangles the different components of this grand project of cultural translation by focusing on a handful of authors: François-Xavier Dentrecolles, Joachim Bouvet, and Claude Visdelou. Of these three, Dentrecolles receives most of her attention. His prolific translations amply justify this importance to her project, since his published works are complemented by selections from his correspondence and other testimony about his understanding of Chinese texts. Wu's book has four main chapters that explore the following themes relating to translation: the education of the translator in Chinese language and thought; the role of the translator in choosing texts within the context of the Rites Controversy; the translator confronting the philosophes on interpretations of Chinese philosophy; and the place of the translator in the transmission of information of a scientific character. In each of these chapters, Wu identifies which Chinese texts were used to produce specific passages in the published writings of the French Jesuits, contrasting the Chinese originals, modern translations, and the Jesuits' versions. Not only does she reveal the variations in emphasis that Jesuit authors put on specific renderings, but she places the Chinese works within their proper literary, philosophical, and scientific contexts. When possible, Wu contrasts the published versions with manuscript sources which further elucidate her theme: Jesuits acting as cultural intermediaries while practicing translation.

What is particularly helpful about Wu Huiyi's Traduire la Chine au XVIIIe siècle is that it revisits some of the commonplaces of French missionary writings: the exchanges with Malebranche, the presentation of Chinese philosophy from seemingly unorthodox sources, the discussion of herbal remedies, as well as silk and porcelain production. Here we see a much deeper analysis than previous generations of scholars have given to those early reports on China: Instead of merely confirming that Jesuit texts intended to be curious and edifying, she asks pointed questions about the origins of their knowledge, 
and succeeds in matching translation to text. To be sure, there remain many more Jesuit texts, whether in print or manuscript, from Ricci's time forward, to which such deep textual analyses should be made, but this first set of analyses is a valuable contribution towards that larger project. Some readers will recall seeing earlier versions in the periodical literature of the chapters of Traduire la Chine au XVIIIe siècle, which originated in Wu Huiyi's doctoral dissertation, but this volume has the virtue of bringing those parts together and framing them within broader considerations of the intellectual exchanges that took place between early modern Europe and China.

\author{
Liam Matthew Brockey \\ Michigan State University \\ brockey@msu.edu \\ DOI:10.1163/22141332-00503007-03
}

